ISSN 1112-9867

Available online at

http://www.jfas.info

\title{
METHOD OF ASSESSMENT THE ANNUAL FLOW OF THE WADI IN THE NORTH OF ALGERIA
}

\author{
M. Ladjel ${ }^{1, *}$ and O. Mezentseva ${ }^{2}$ \\ ${ }^{1}$ University Abderrahmane Mira, Bejaia, Algeria \\ ${ }^{2}$ Omsk State Pedagogical University, Russia
}

Received: 17 December 2015 / Accepted: 08 April 2016 / Published online: 01 May 2016

\begin{abstract}
In arid and semiarid climatic conditions of Northern Algeria surface water resources are limited and irregular in time and space. The water resources of the ephemeral streams (Wadi) are associated with the precipitation and depend on the latitude and altitudinal zonation. Large catchments drained the whole total runoff, which is equal to the difference between precipitation and evaporation. Groundwater runoff of small and medium rivers is proportional to the catchment area; evaporation is influenced by local factors. This paper proposes a new approach to the analysis of the geographical distribution of runoff specifying the vertical and latitudinal zonation of flow and the influence of the basin morphology. The transition from the climatic runoff estimates to the river runoff estimates was made using the Climatic factor of module local runoff, which can be mapped.
\end{abstract}

Keywords: precipitation; climate runoff; river flow; evaporation; potential evaporation.

Author Correspondence, e-mail: ladjel_mahmoud@yahoo.fr

doi: http://dx.doi.org/10.4314/jfas.v8i2.10

\section{INTRODUCTION}

Northern Algeria is characterized by contrasting topography of the Atlas Mountains and Mediterranean climate, which determine the mode of the renewable water resources of surface waters. Precipitation mostly as rain, with high spatial and temporal variability, their number in the West is a layer of about $350 \mathrm{~mm}$ in average years and may exceed $1000 \mathrm{~mm}$ per year average in the North-East. Annual precipitation decreases from North to South, and 
precipitation usually occur within a few months of the year, mainly from September to April. Climatic conditions significantly affect the landscapes of Algeria, especially in mountainous and steppe areas, which cover about $60 \%$ of the Northern part of the country where the main population and are concentrated the most fertile land.

Hydrometric measurements of flow of the rivers is carried out by the National Agency for water resources (ANRH), with more than 160 hydrometric stations, most of which are located at the mouths of large and medium sized catchments. The number of river basins with an area less than $100 \mathrm{~km}^{2}$ representing $12 \%$ of all basins of Algeria. Currently the duration hydrometrics observations on the rivers are on average 25 years. The river flow depends entirely on the regime of precipitation and its distribution in space.

Integrated water resources management in the country is a serious problem; it is due to spatial and temporal variations of own characteristics. Surface runoff accounts for a large portion of the total river flow, ensuring the existence of saline lakes or flows into the Mediterranean Sea. Its quantative estimates for small catchments are important for the design of small reservoirs and local water supply. In the absence of hydrological data for estimating runoff of small and medium catchments we used a water-balance calculation method and the territorial generalization of the hydro-climatic characteristics, proposed by V. S. Mezentsev.

Using in work cartographic mapping method of the independent climatic characteristics of the flow we recieve plausible expression its spatial patterns, as well as evaluations of the annual runoff.

\section{ON THE STATUS OF THE ISSUE}

Assessment of river runoff in semi-arid climates remains a major issue in applied hydrology, especially for unreached hydrological observations catchments. At the same time, the economic and social development of the country largely depends on the capacity of water resources. The main source of meeting the ever increasing demand for freshwater in most cases is surface water resources estimated as the long-term average annual river runoff (AARR). Theoretically AARR is the arithmetic mean from a sufficiently long series of values of annual runoff that contains an integer hydrological cycles. In this case, it is considered as climatically stable and determines the water potential of the region.

On large catchments, long-term average annual river runoff (AARR) depends on major climatic factors: mean precipitation and evaporation. The underlying surface factors make an impact on runoff using precipitation and evaporation on the surface of the catchment. 
Long-term average annual river runoff (AARR) with small and medium catchments is under the predominant influence of local physiographic factors, and to a lesser extent under the influence of zonal climatic factors. As a rule, precipitation increases with height, while with increasing height the evaporation is reduced due to lower temperatures and decrease in radiation balance. The exposition of the slopes to the direction of humid and warm winds has a great impact on the territorial distribution of precipitation and evaporation. Therefore, the relationship between AARR and the average height of the catchment areas are local in nature. The increase in the slope of the catchment area reduces evaporation losses and increases the AARR. Permeable soils and rocks quickly absorb some rainfall. In this case, the atmospheric moisture are less susceptible to evaporation. Waterproof breed contribute to the retention of precipitation on the surface and increase the evaporation. The increase in the slope of the catchment area reduces evaporation losses and increases AARR. Permeable soils and rocks quickly absorb some rainfall. In this case, the atmospheric moisture is less susceptible to evaporation. Waterproof breed contribute to the retention of precipitation on the surface and increase the evaporation. Thus, the influence of underlying surface on the runoff is evident through evaporation.

For most small and medium-sized rivers, especially in semi-arid zone, climatic zonal flow is determined by a map of isolines of the module or layer of a drain. It may differ significantly from the values of the river runoff, actually measured in the closing range of the watershed [9, 10]. Deviations of calculated and actual discharge values for small mountain rivers may reach in some cases more than $100 \%$. The local character of precipitation on rugged terrain, and lithology of rocks affecting the replenishment of aquifers, manifested mainly on the catchments of small and medium rivers.

Currently in Algeria for estimates of runoff are using simplified empirical formula, not taking into account the influence of local factors on runoff. These formulas are expressed in terms of dependencies between the drain and the amount of precipitation, sometimes between the drain and a catchment area or temperature.

In practice of hydrological calculations there is a need to develop a method that corresponds to various aspects of the Genesis of runoff in semi-arid climatic conditions with the influence of local factors that are not measurable.

\section{THE HISTORY OF RIVER RUNOFF CALCULATIONS DEVELOPMENT}

Assesment of long-term average annual river runoff (AARR) on the basis of meteorological data using the water balance equation is the difference of the long term average precipitation 
and average annual evaporation. This approach is valid for closed river basins draining the total flow, which depends on climatic factors - rainfall and evaporation. The equation of water balance to estimate runoff from large catchments was used in the end of XIX century by A. I. Voeikov [1] A. Penk [17]. In the early twentieth century A. Penk [17] and G. Keller [4] expressed AARR in the form of a linear function of mean precipitation.

Then in 1904, P. Schreiber [19] and in 1911 E.M. Oldekop [15] suggested a universal model of total runoff $Y_{o}$ and evaporation $Z_{o}$, depending on rainfall $X_{o}$ and evapotranspiration adopted as the characteristic of thermal resources of climate, determined by the radiation balance. So the Genesis of river flow has acquired an energy basis. In the middle of the XX century M.I. Budyko [2] generalized the formulas of Schreiber and Oldekop in the form of geometric mean of expression.

Currently, among the methods for calculating evaporation from the surface most commonly used methods, based on the relationship with maximum possible evaporation and precipitation.

In 1955-1957 V.S. Mezentsev proposed equation, the actual evapotranspiration [12,13 ] in the following form: $Z_{o}=Z_{\max }\left[1+\left(\frac{X_{o}}{Z_{\max }}\right)^{-n}\right]^{-\frac{1}{n}}$, where $n-$ is a parameter characterizing the hydraulic conditions of flow and evaporation formation in the catchment (depends on the type of relief and is an empirical). The maximum possible (potential) evaporation $Z_{\max }$ is considered as the aquatic equivalent of heat and power resources of climate and clarified them is part of the equation of heat balance of the earth's surface. That formula is valid for large catchments with climatic runoff which is affected by precipitation and evaporation and does not depend on azonic factors.

The development of methods for the estimation of AARR in Algeria repeats the situation of European countries. Some empirical formulas have been developed for Wadi of Algeria by hydrologist Samie [18], who proposed the expression in which runoff increases with precipitation and decreases with increasing catchment area. The runoff equation proposed by Turk [20] and Coutagne [3] include only precipitation and temperature. Padoune E.N. [16] believed that the rainfall, topography and distance from the sea play a fundamental role in the formation of runoff. On this basis he determined the dependence between the module of average runoff $\left(l / s \cdot \mathrm{km}^{2}\right)$, average basin altitude and precipitation. Ladjel M. [5,6,7,8,9], expressed a total losses of runoff $P_{r}=X_{o}-Y_{o}$ in the form of a monomial $X_{o}{ }^{m_{o}}$ with 
exponents $m_{o}=C_{\mathrm{m}} \prod_{i=1}^{N} \Phi_{i} \frac{n_{X_{i}}+1}{N}, N$-factor and $\Phi_{i}$-conversion. In this case the climatic factor $C_{m}$ can be mapped.

\section{BASELINE HYDRO-CLIMATIC DATA}

In the present work for calculations used hydro-climatic data of National Agency of hydraulic resources of Algeria. Hydrological and morphometric information relates to 77 the catchment area of $19 \mathrm{~km}^{2}$ to $2085 \mathrm{~km}^{2}$ in the Northern part of Algeria: hydrometric data (average daily flow) and morphometric data (drainage area, river length and average gradient of the river). The average length of the row of hydrometric observations in the Algeria is approximately 26 years. The long term average precipitation during the calculation period (60 years) taken for the hydrological gravity centre of the catchment area with contour map. Maximum posible (potential) evaporation is also defined on the map of contour lines developed by the same Agency.

\section{THE RESULTS OF THE ANALYSIS OF THE RELATIONSHIP BETWEEN RUNOFF AND CLIMATIC CHARACTERISTICS IN NORTHERN ALGERIA}

In semi-arid climatic conditions, especially in conditions with difficult relief, the runoff formation factors are determined by physical-geographical conditions and depend on latitudinal and altitudinal climatic zonality. Factors of the underlying surface, such as vegetation and soil cover, also depend on climatic factors and altitude, especially from the location of the slope in relation to the moist or dry hot winds and to the sun exposure.

Thus, the Genesis river flow is the result of combined effects of climatic factors (precipitation, evaporation) and local factors (soil type, vegetation, depth of groundwater, the mechanical composition of the soil, slope and roughness of the catchment). Local factors determine the amount of losses of river flow.

The equation of water balance for a catchment can be expressed as:

$$
Y_{o}=X_{o}-P_{o}
$$

where: $Y_{o}$ - river runoff, $\mathrm{mm} ; X_{o}$ - precipitation, $\mathrm{mm} ; P_{o}-$ loss of flow, $\mathrm{mm}$.

To determine river flow for ungauged catchments only information about precipitation is not enough. We should also know the losses of river flow (water losses) in the catchment. This issue must be addressed with the use of geographic territorial generalizations that, in our opinion, will allow us to estimate long-term average runoff for all watersheds regardless of 
size. Mean the search of the independent characteristics of the average flow, which can be mapped and represented in the form of the contour field.

The dependence $Y_{o}=f\left(X_{o}\right)$ in the North of Algeria reflects the increase in runoff following a precipitation increase (Fig. 1). There is a minimum value $X_{o \text {, min }}$ below which the flow tends to zero. Analysis of the dependence $Y_{o}=f\left(X_{o}\right)$ shows two regions of precipitation changes on the chart. For values $X_{o}>600 \mathrm{~mm}$, the dependence $Y_{o}=f\left(X_{o}\right)$ is practically linear, and for values $X_{o}<600 \mathrm{~mm}$ the dependence $Y_{o}=f\left(X_{o}\right)$ becomes curvilinear. Many of the watersheds of semi-arid areas of Algeria belong to this curved area that highlights the complexity of the runoff genesis.

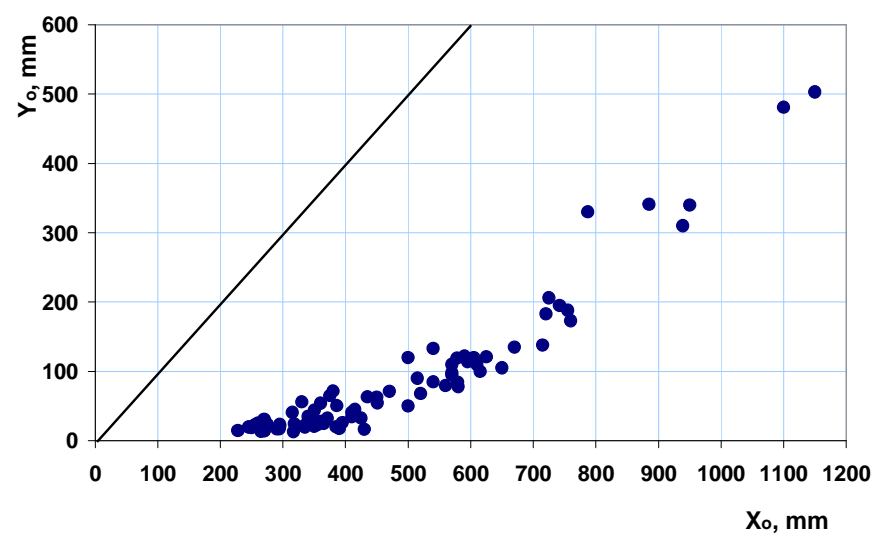

Fig.1. Graph of the dependence of the river runoff from precipitation $Y_{o}=f\left(X_{o}\right)$

The dependence of river runoff from latitude $Y_{o}=f(Y)$ shows the presence of some latitudinal climatic zonality of the flow, but with considerable dispersion of the points within the same latitude. On the chart (Fig. 2) shows that for latitudes $Y=36.5^{\circ}$ the flow varies from $100 \mathrm{~mm}$ to $500 \mathrm{~mm}$ per year. That is not possible in the Northern part of Algeria, use latitude as the sole factor for map display river flow.

Consider the following two equations of water balance [11]:

$$
\begin{aligned}
& X_{o}=Y_{o}+P_{o} \\
& X_{o}=Y_{c \lim }+Z_{o}
\end{aligned}
$$

where: $Y_{c l i m}-$ long-term average climatic runoff (depends on climatic conditions), $\mathrm{mm} ; Z_{o}-$ evaporation from the catchment area, $\mathrm{mm}$. 


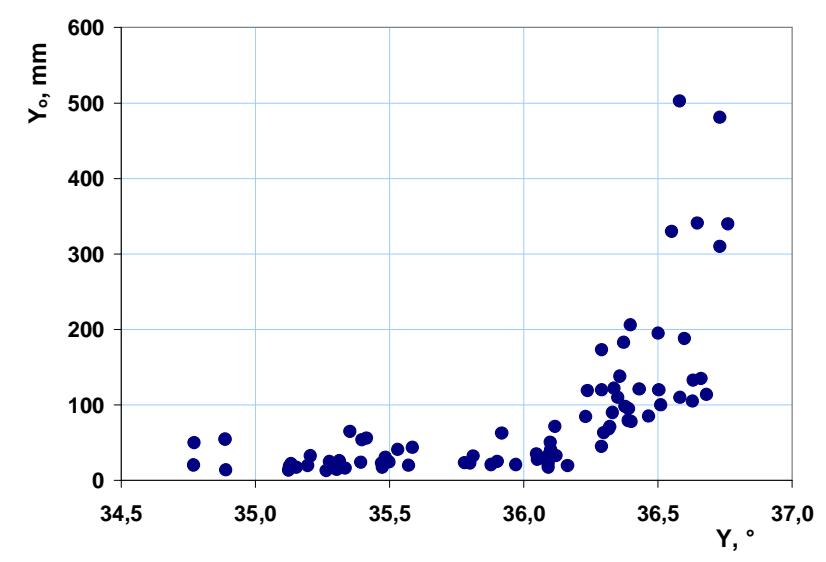

Fig.2. Graph of the dependency of river runoff from the latitude $Y_{o}=f(Y)$

In the climatic conditions of the North of Algeria value of runoff is always greater or equal to the magnitude of the climatic runoff, that is $Y_{o} \geq Y_{c \lim }$. At the same time graphical analysis of the dependencies $Y_{o}=f(S)$ and $Y_{c \lim }=f(S)$ shows that with increase in catchment area $S$, the values of the river flow $Y_{o}$ increase and approach to climate flow $Y_{c \text { lim }}$, but for small and medium catchments, the difference $\left(Y_{c \lim }-Y_{o}\right)$ are significant, especially for areas of the watershed less than $500 \mathrm{~km}^{2}$ (Fig. 3). Figure 4 shows that the reduction of the difference values of river runoff and climatic runoff (Fig. 3) is directly connected with the decrease of precipitation depending on the increase of catchment areas.

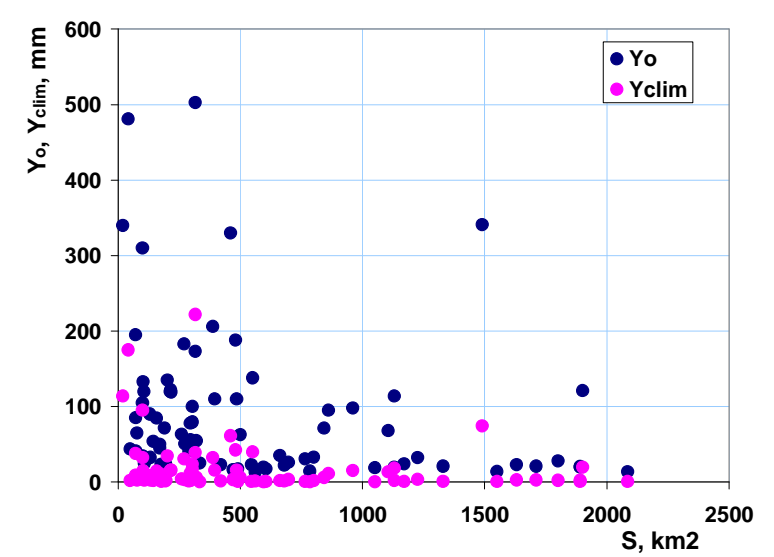

Fig.3. Graph of the dependency of river flow $Y_{o}=f(S)$ and climatic runoff $Y_{c \text { lim }}=f(S)$ from the catchment area 


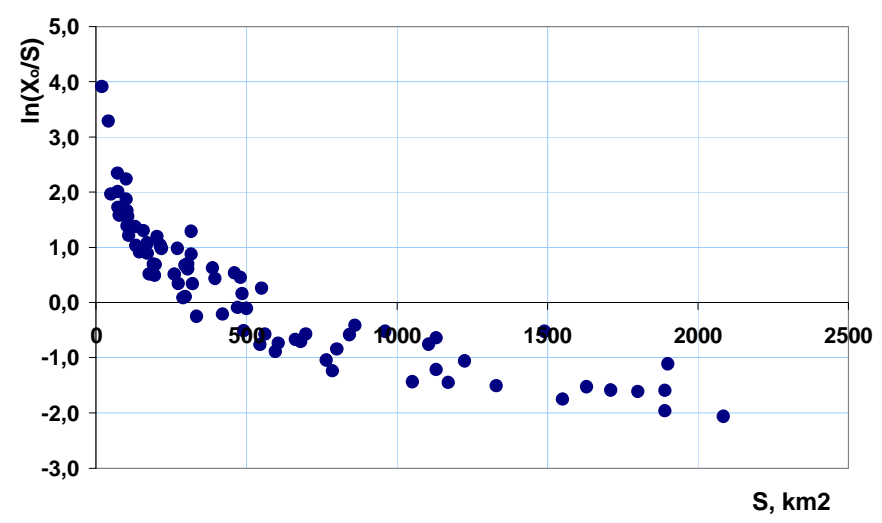

Fig.4. Graph of module of precipitation from the catchment area $X_{o} / S=f(S)$

From equations (2) and (3), for the centers of gravity of river basins can be obtained:

$$
Y_{c \lim }-Y_{o}=P_{o}-Z_{o}
$$

In the same climatic and physiographic conditions, the increase of the catchment area causes a decrease in the difference between the two types of flow that tends to the minimum value, close to zero. The larger the catchment, the closer the drainage of groundwater by the river to the maximum, this means that the equality $Y_{o}=Y_{c \lim }$. At the same time, the share of the total losses of precipitation to evaporation and infiltration into the groundwater maximum in small areas of watersheds. This leads to a significant difference $Y_{c \lim }$ at the hydrological center of the catchment and $Y_{o}$ in the closing range.

As noted above, climatic runoff $Y_{c \lim }$ is a function solely of the climatic factors: precipitation $X_{o}$ and evaporation $Z_{o}$. In this work the assessment of climatic runoff was conducted according to the formula V.S. Mezentsev [12, 14].

$$
\begin{aligned}
& Y_{c \lim }=X_{o}-Z_{o} \\
& Z_{o}=Z_{\max }\left[1+\left(\frac{X_{o}}{Z_{\max }}\right)^{-n}\right]^{-\frac{1}{n}}
\end{aligned}
$$

where: $Z_{\max }-$ the maximum possible (potential) evaporation, water equivalent of heat and power resources of climate, $\mathrm{mm}$; $n$ - the indicator (parameter) characterizing the hydraulic conditions of flow formation and evaporation in the catchment (takes into account the catchment relief, varies in Northern Algeria within the limits of 1,5-3,0 from the mountains to the plains). 
The relationship of climatic runoff for 77 watersheds in Northern Algeria with latitude is shown in Fig. 5.

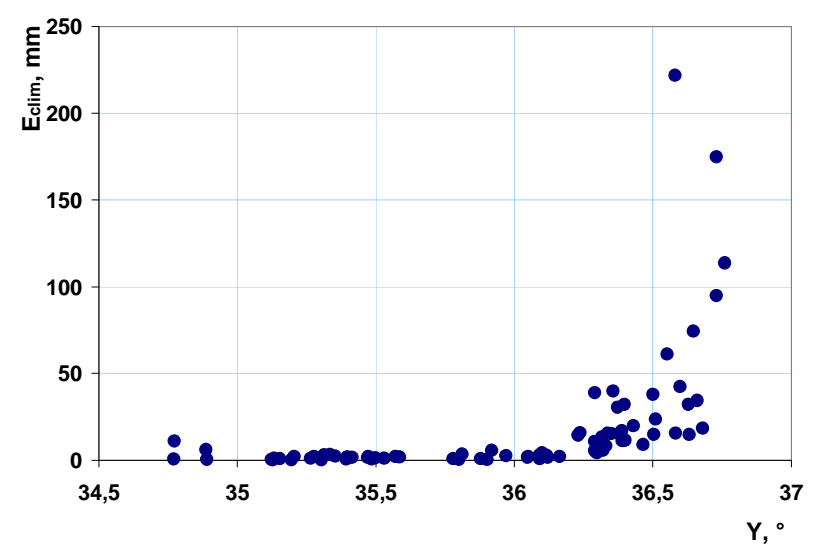

Fig.5. Graph of climatic runoff from the latitude $Y_{c \lim }=f(Y)$

The difference of climatic runoff $Y_{c \text { lim }}$ and river flow $Y_{o}$ can be expressed in the form $Y_{l o c}=Y_{o}-Y_{c \lim }$ and marked as local runoff, which is generated by precipitation under the influence of factors of the underlying surface. It would seem that the coefficient of local runoff $\alpha_{l o c, 1}=\frac{Y_{l o c}}{X_{o}}$ represents the perfect response to solve the problem, but since the values of precipitation depend on the area of the catchment (Fig. 4), it is necessary in the denominator to take into account not the absolute value of rainfall and the module (precipitation on a unit area) $\frac{X_{o}}{S}$.

The result is a specific coefficient of local runoff

$$
\alpha_{l o c, 2}=\frac{Y_{l o c}}{X_{o} / S},
$$

which should be relatively independent from anything that can include a river-drained area (intra-zonal effect). But the view and analysis of the dependence $\alpha_{l o c, 2}=f(S)$ show that this coefficient still depends on the area size (Fig. 6). 


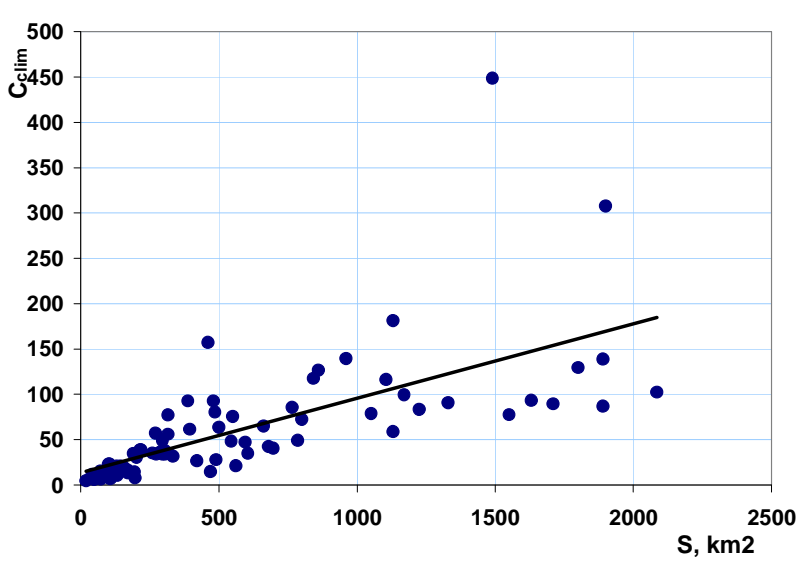

Fig.6. Graph of specific coefficient of local runoff from the catchment area $\alpha_{l o c, 2}(S)$

While the hilly topography of the catchment, shape of the catchment affects the seeking of surface runoff and underground runoff, and runoff losses from evaporation. You should also consider the average slope of the watershed. Denoting these effects as morphometrically factor $\Phi$ which distinguishes catchments on their shape and area, we express it in the form $[10,11]$ :

$$
\Phi=I \frac{B}{l_{p}}
$$

where: $I=\frac{H_{\max }-H_{\min }}{l_{p}}-$ average slope of the watercourse; $H_{\max }$ and $H_{\min }$, respectively, marks of the headwaters and river mouth; $l_{p}$ - the length of the watercourse; $B=S / l_{p}-$ average width of catchment.

Transforming the expression (7), substitute it in morphometric factor $\Phi$ and obtained the following expression:

$$
C_{c \lim }=\alpha_{l o c, 3}=\frac{Y_{l o c}}{\left(X_{o} / S\right)^{1 / \Phi}}
$$

Now converted specific coefficient of local runoff $\alpha_{l o c, 3}$ will be called a climatic factor of module local runoff and denote $C_{c \lim }$. Graphical analysis of the dependence $C_{c \lim }(S)$ shows that $C_{c l i m}$ does not depend on the size of the catchment area (Fig. 7). 


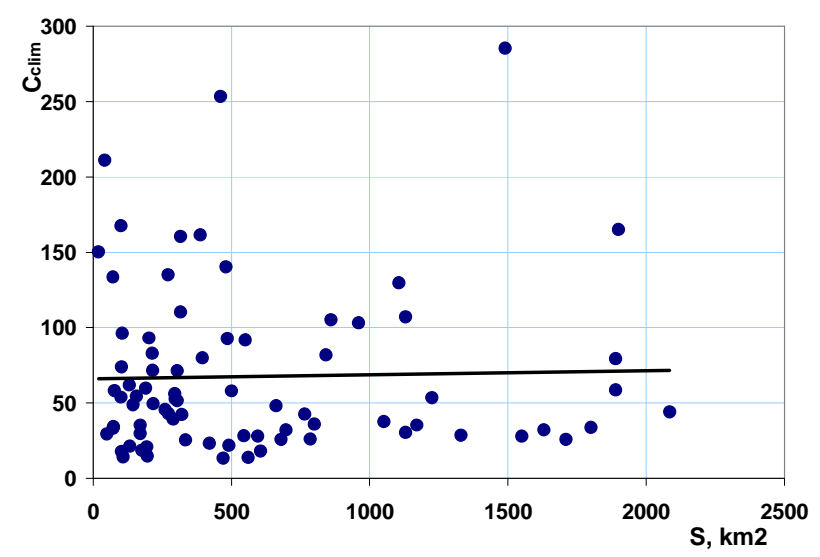

Fig.7. Graph of $C_{c \lim }(S)$

Climatic factor of module local runoff $C_{c \lim }$ should vary proportionally with the climatic water balance elements. Graphical analysis of the dependence with precipitation $C_{c \lim }=f\left(X_{o}\right)$ confirms the presence of correlation (Fig. 8). Latitudinal distribution of this coefficient is consistent with the climatic distribution of presipitation (Fig. 9). Thus, climatic factor of module local runoff depends on climatic (zonal) factors, therefore, may be mapped and displayed in the form of the contour field (Fig. 10).

Now an estimate of AARR for any hydrologically ungauged watershed area becomes possible. You need to have information about the catchment area, to know the average multiyear annual precipitation and the maximum possible (potential) evaporation $Z_{\max }$. To obtain runoff estimates should be calculated evaporation $Z_{o}$ according to the formula (6) and also the value of climatic factor of module local runoff $C_{c \lim }$ should be determined by linear interpolation on the map.

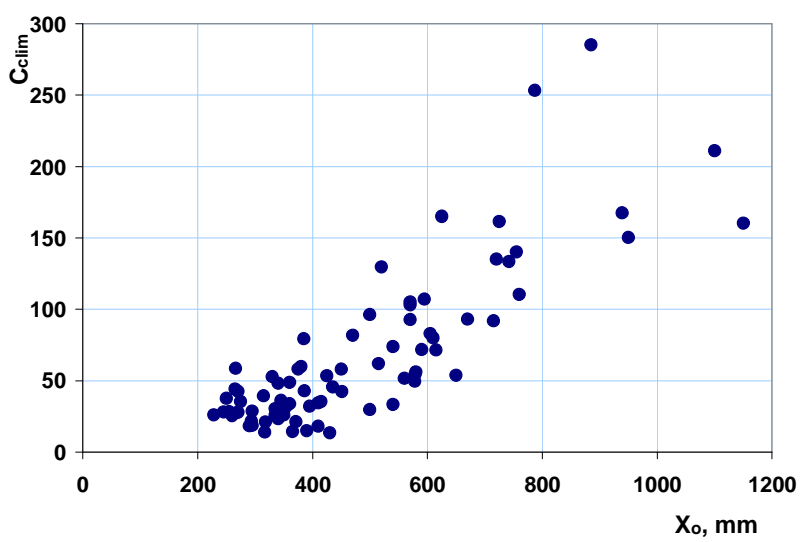

Fig.8. Graph of the climatic factor of module local runoff from precipitation $C_{c \lim }\left(X_{o}\right)$ 


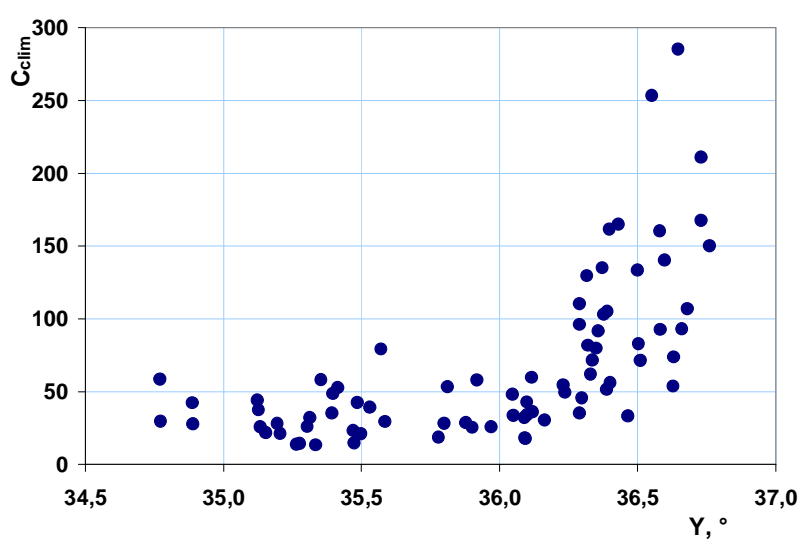

Fig.9. Graph of the climatic factor of module local runoff from latitude $C_{c \lim }=f(Y)$

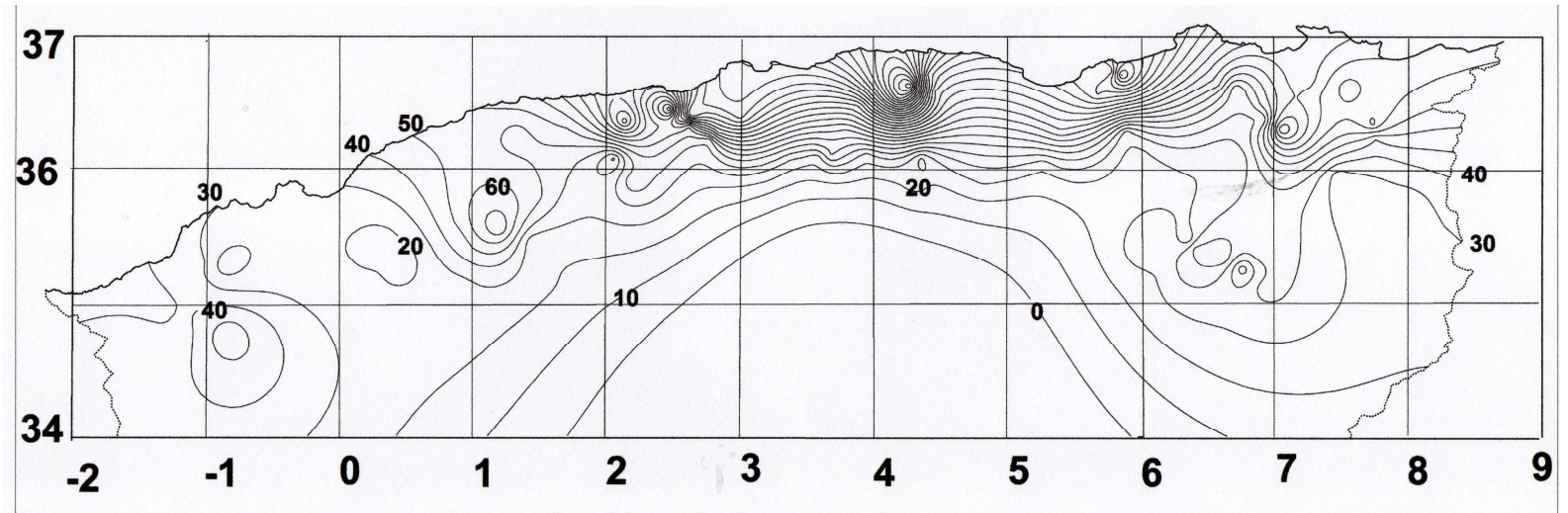

Fig.10. The isolines of the climatic factor of module local runoff $C_{c \lim }$ for the Northern part of Algeria

Losses of flow are determined by the following expression:

$$
P_{o}=Z_{o}-C_{c \lim }\left(\frac{X_{o}}{S}\right)^{1 / \Phi}
$$

The value of river runoff is calculated by the equation of water balance (1). The accuracy of the runoff calculation depends mainly on the accuracy of the average values of characteristics: precipitation $X_{o}$, maximum possible (potential) evaporation $Z_{\max }$ and climatic coefficient $C_{c \lim }$ for hydrological catchment gravity centres.

\section{CONCLUSION}

Analysis of the dependency between the river runoff and its genetic factors in conditions of Algeria confirmed the duality of the river flow, the presence of its climatic and local components. The climatic component of the runoff depends solely on zonal climatic factors. The second component of the river flow also depends on the climate, but locally (relative to 
the unit area in this point). The territorial generalization of this regularity in the form of a map of the climatic factor of module local runoff allows to estimate the value of losses of runoff for any drainage basin. A zero value of this coefficient on the map shows the boundary between semi-arid and arid zones of North Algeria. This approach can be recommended for estimates of river flow regulations other semi-arid regions where gauging information flow is insufficient. The same approach we recommend for calculations of the average annual river runoff by months.

\section{REFERENCES}

[1] Воейков А. И. Климаты земного шара, в ообенноти Рассии. Изд. АН СССР, 1948.

[2] Будыко, М.И. Об определении испарения с поверхности суши // Метеорология и гидрология. -1955. - №1. - С. 52-58.

[3] Coutagne, A. Contribution à l'étude de l'écoulement en Algérie, Annuaire hydrologique de l'Algérie 1947/48, DSCH SCEGGT, Alger, pp 3-55.

[4] Keller, H. Niederschlag, Abflus und Verdunstung in Mittelleuropa // Jahrbuch fur Gewasserkde. Bsondere Mittelungen/-1906. -Bd.1-N 4. -S.3-12

[5] Ladjel, M. Cartographie de l'écoulement moyen interannuel (Les ressources hydriques superficielles). Algérie-EQUIPEMENT. Revue technique de l'Ecole Nationale des Travaux Publics. $n^{\circ} 36$, décembre 2002.

[6] لعجال محمود تقدير الخصائص الهيدرولوجية المتعلقة بحساب السدود. مؤتمر تقويم تجربة الوطن العربي في إقامة

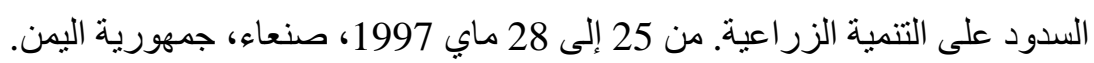

[7] Ladjel, M. Contribution à la méthode de cartographie de l'écoulement moyen interannuel (EMI) des cours d'eau du bassin méditerranéen. Conférence Internationale de Géoengineering 2000, les 11, 12 et 13 juin 2000, U.S.T.H.B., Alger.

[8] Ladjel, M. Evaluation and Storage of Water Resources in Semi-Arid Regions. The International Conference on Water Resources Management in Arid Regions. 23-27 March, 2002. Kuwait.

[9] Ladjel, M. Application des modèles climatiques globaux pour l'estimation de l'écoulement moyen interannuel du bassin de la Seybouse. SNHC08, Université Hassiba Benbouali de Chlef. 2008.

[10] Ladjel, M. Ecoulement des oueds des régions arides et semi-arides. $1^{\text {ier }}$ Séminaire National sur l'Eau et l'Environnement dans les Zones Arides (SNEEZA 2015), 19-20 avril 2015, Ouargla. 
[11] Ladjel, M. Approche climatique d'estimation des ressources en eau superficielles du Nord de l'Algérie. $1^{\text {ères }}$ Journées Nationales d'étude sur les Géosciences «Géosciences et Développement Durable», 30 novembre et $1^{\text {ier }}$ décembre 2015, Sétif.

[12] Мезенцев, В.С. Метод гидролого-климатических расчетов и опыт его применения для районирования Западно-Сибирской равнины по признакам увлажнения и теплообеспеченности. //Тр.ОмСХИ. - Омск: Изд-во ОмСХИ, 1957. - Т.27. - 121 с.

[13] Мезенцев, В.С. Гидрологические расчеты в мелиоративных целях. Учебное пособие. Омск: Изд-во ОмСХИ, 1982. - 80 с.

[14] Мезенцева, О.В. Использование метеорологической информации для количественной оценки местных водных ресурсов малоизученных территорий // Фундаментальные исследования. 2013. № 10-12. С. 2690-2694.

[15] Ольдекоп, Э. М. Об испарении с поверхности речных бассейнов. Юрьев, 1911.

[16] Падун Е.Н. Сток алжирских вади. кандидатская диссертацияб, 1972. Киев.

[17] Penck, A. Niederschlag und Abfluss in Mitteleuropa. Forsch. d. D. Land und Volkskunde, 1903.

[18] Samie, C. Monographie du bassin de la Mafragh, Alger, Annuaire hydrologique de l’Algérie (année 1956-57), pp. 1-67.

[19] Schreiber, P. Ueber die Beziehungen zwischen dem Niederschlag und der Wasserfu“ hrung der Flüsse in Mitteleuropa. Meteor. Z., 21, 441-452, 1904.

[20] Turc, L. Le bilan d'eau des sols. Relation entre la précipitation, l'évaporation et l'écoulement. Ann. Agron., 5, 491-569, 1954.

\section{How to cite this article:}

Ladjel $\mathrm{M}$ and Mezentseva O. Method of assessment the annual flow of the Wadi in the north of Algeria. J. Fundam. Appl. Sci., 2016, 8(2), 313-326. 